\title{
MECHANICAL PROPERTIES OF AISi12 ALLOY WITH ALUMINIUM BRONZE
}

\author{
Tomasz Lipinski \\ University of Warmia and Mazury in Olsztyn, Poland \\ tomaszlipinski.tl@gmail.com
}

\begin{abstract}
One of the most common castings applied in industrial production is aluminum-silicon alloy (ca. $12 \%$ $\mathrm{Si}$ ). Non-modified Al-Si alloy is characterized by coarse-grained structure, responsible for its poor physicochemical properties. The microstructure and mechanical properties of hyper-eutectic silumins may be improved by modification with chemical elements and technological processing. This paper presents the research of treatment AlSi12 alloy with composition CuAl10Fe3Mn2 + Al12Si+CuAl10Fe3Mn2 + Cu in different ranges. The experiments was conducted by a factor plan $2^{3}$ for three independent variables. The main addition was aluminum bronze, as well as pure or melted with raw alloy and pure $\mathrm{Cu}$. The effect of the tested modifiers on the microstructure and mechanical properties of the AlSi12 alloy was presented in figures. All analyzed parameters of the hypo-eutectic AlSi12 alloy with the tested mixtures are improved. Based on the analysis of the study results it was found that the microstructure and mechanical properties of the tested alloy are determined through the contents and chemical composition of mixtures introduced to the alloy. Pre-melting aluminum bronze has been found to be important for increasing the effectiveness of its impact on the microstructure and the investigated mechanical properties. Grain refinement was observed, and eutectic AlSi12 silicon had oval morphology with smaller size.
\end{abstract}

Keywords: silumin, aluminum bronze, Al-Si alloy, modification,mechanical properties, microstructure.

\section{Introduction}

Hypo-eutectic AlSi12 alloy is one of the most popular casting Al-Si alloys. Popularity is owing to their low melting point, relative low contraction, low price, good corrosion resistance and high tensile strength with low specific gravity, easy to carry out the casting process. The aforementioned features of this alloy cause to use it in the manufacture of pistons of combustion engines. The microstructure of raw AlSi12 alloy consists of a large well deformable alpha phase and sharp-pointed hard, nondeformable beta phase. These unmodified phases of microstructure composition give the alloy a low tensile strength and elongation close to zero. This is the reason for not using alloy in this form [1-3].

The microstructure and closely related with it properties AlSi12 silumin requires a change, like that of all casting alloys [4-7], through modification or processing [8-16]. In the majority of cases alloys are modified to change the form and size of grains, mostly silicon grains, which reduces the interphase spacing of eutectic $(\alpha+\beta)$ and reduces the size of the primary alpha, but first of all large beta phase [1]. The researches indicate that the reaction thermal effects as a solidification process affect the result of the modification process, what causes changes in the size and shape of alloy phases and obtaining the expected properties of the alloy [8-16].

There are other effective methods of treatment silumins. Interesting and modern methods are modification by the use of homogenous modifiers [10;11], as well as exothermic modifiers that produce exothermic effects in the modification process of alloys [12; 16].Modification with exothermic modificator allows to enter chemical elements into liquid alloy. The chemical elements are introduced not only to improve the microstructure of the treated alloy but also to increase its performance characteristics. The alpha dendrites phase is difficult to modification. The beta phase is usually modified. Because of this improvement the properties of Silumin depend on modification of the beta phase $[1 ; 16]$. Siluminmodification with modifiers composed of several components (mixtures) is more effective than modification with individual alloy-forming elements. The above applies to both homogeneous [10] and exothermic modifiers [12-16].

The results of studies on the change of the microstructure of nearly-eutectic aluminum-silicon liquid alloys mainly with sodium and strontium and other chemical elements and mixtures already tested are published and described by many authors $[1 ; 8 ; 9]$.However, widely presented books and research papers on the silumin treatment do not give a lot of contents on the effect treatment with $\mathrm{Cu}$ and aluminum bronze. In view of the high popularity of AlSi12 alloys the purpose of the study was to determine the mechanical properties of hypo-eutectic silumin AlSi12 modified with CuAl10Fe3Mn2 + $\mathrm{Al} 12 \mathrm{Si}+\mathrm{CuAl10Fe} 3 \mathrm{Mn} 2+\mathrm{Cu}$ in different range of components. 


\section{Materials and methods}

The experiment was performed on EN AB- AlSi12 hypoeutectic alloy [17], produced industrially and supplied in the pig sows. The chemical composition of raw AlSi12 alloy is presented in Table 1.

Table 1

\section{Chemical composition of AlSi12 alloy}

\begin{tabular}{|c|c|c|c|c|c|c|c|c|c|c|}
\hline \multirow{2}{*}{ Alloy } & \multicolumn{10}{|c|}{ Chemical composition, wt. \% } \\
\cline { 2 - 10 } & $\mathrm{Si}$ & $\mathrm{Cu}$ & $\mathrm{Mg}$ & $\mathrm{Mn}$ & $\mathrm{Fe}$ & $\mathrm{Ti}$ & $\mathrm{Ni}$ & $\mathrm{Zn}$ & $\mathrm{Pb}$ & $\mathrm{Al}$ \\
\hline AlSi12 & 11.2 & 0.10 & 0.10 & 0.42 & 0.45 & 0.10 & 0.08 & 0.12 & 0.10 & ball \\
\hline
\end{tabular}

The alloy was melted in a ceramic crucible in an laboratory electric furnace Nabertherm 30 3000. The treatment process was performed with $\mathrm{Cu}, \mathrm{CuAl} 10 \mathrm{Fe} 3 \mathrm{Mn} 2$ and mixtures with $50 \%$ $\mathrm{CuAl} 10 \mathrm{Fe} 3 \mathrm{Mn} 2+50 \% \mathrm{Al} 12 \mathrm{Si}$. The alloy was melted at $750^{\circ} \mathrm{C}$ for 8 minutes. Dry sand molds formed in the shape of a cylinder of $75 \mathrm{~mm}$ in length and $8 \mathrm{~mm}$ in diameter were filled with the liquid of AlSi12 alloy with modifier. From each casting two specimens were obtained. The Brinell method determined hardness by using a test force value of $612.9 \mathrm{~N}$, ball diameter of $2.5 \mathrm{~mm}$; the forcediameter index was 10 and the duration time of the test force $20 \mathrm{~s}$. Hardness was measured on the side surface of the head of the test pieces prepared to tensile test prepared by grinding to a depth of $2 \mathrm{~mm}$. Three hardness measures per sample (6 measurements per cast) were made.All Brinell hardness measurements were performed according to the standard EN ISO 6506-1:2014 [18] in the HPO 250 hardness tester. The tensile stress test was carried out on the test pieces with ratio of 1:5 (a diameterto-length) by using the ZD-30j universal tensile tester to determine the ultimate tensile strength and percentage elongation. The tensile strength and elongation test was carried out on two $\phi 6 \mathrm{~mm}$ samples for each research point, according to the standard EN ISO 6892-1:2016 [19]. The experiments were conducted by a factor plan $2^{3}$ for three independent variables. The variable and its levels are presented in Table 1. The regression equation for each research parameter was presented as (1).

$$
\hat{y}=b_{0}+b_{1} x_{1}+b_{2} x_{2}+b_{3} x_{3}+b_{12} x_{1} x_{2}+b_{13} x_{1} x_{3}+b_{23} x_{2} x_{3}+b_{123} x_{1} x_{2} x_{3} \text {. }
$$

\section{Level of variables}

Table 1

\begin{tabular}{|c|c|c|c|c|}
\hline Variable & $\begin{array}{l}\text { Primary } \\
\text { level, \% }\end{array}$ & $\begin{array}{c}\text { Range of } \\
\text { changes, \% }\end{array}$ & $\begin{array}{c}\text { Higher level, } \\
\% \\
\end{array}$ & $\begin{array}{c}\text { Lower level, } \\
\% \\
\end{array}$ \\
\hline $\mathrm{Cu}$ & 2 & 1 & 3 & 1 \\
\hline CuAl10Fe3Mn2 & 2 & 1 & 3 & 1 \\
\hline 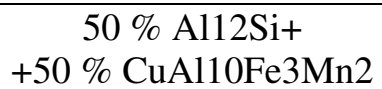 & 4 & 2 & 6 & 2 \\
\hline
\end{tabular}

The results have been subjected to statistical analysis at the level of significance $\alpha=0.05$. The adequacy of the regression equation was verified by means of the Fischer criterion for $p=0.05$.

\section{Results and discussion}

The microstructure of AlSi12silumin without modifying additives consists of a solid solution of silicone in aluminum (phase $\alpha$ ) and a solid solution of aluminum in silicone (phase $\beta$ ) (Fig. 1).

The results of theultimate tensile strength (UTS) of AlSi12 alloy with modifier (Table 1) are shown in Fig. 2 and 5, percentage elongation (A) in Fig. 3 and 6, and Brinell hardness (HB) in Fig. 4 and 7.

Due to difficulties with representing functions for three independent variables, figure drawings for the obtained function were developed from the experimental design on the assumption that each of the analyzed modifier components was present at a stable higher $(3 \%)$ or lower $(1 \%)$ level while the share of the remaining two components varied. Based on this approach, six graphic forms were developed and two presented (Fig. 2-4) for three modifier components.

For raw AlSi12 alloy, the average ultimate tensile strength for four test pieces was defined at $\mathrm{UTS}=153 \mathrm{MPa}$, elongation at $\mathrm{A}=0.5 \%$, and Brinell hardness at $\mathrm{H}=82 \mathrm{HB}$. Treatment with $1 \% \mathrm{CuAl} 10 \mathrm{Fe} 3 \mathrm{Mn} 2+2 \% \mathrm{Al} 2 \mathrm{Si}+\mathrm{CuAl} 10 \mathrm{Fe} 3 \mathrm{Mn} 2+1 \%$ Cuincreased the ultimate tensile strength to 
$170 \mathrm{MPa}$ and Brinell hardness to $84 \mathrm{HB}$. Elongation is the same. After increasing the content of $\mathrm{Cu}$ of the mixture to $3 \%$ the tensile strength is the same (Fig. 2a), elongation increased by $0.2 \%$ to $0.7 \%$ (Fig. 3a) and hardness increased by $3 \mathrm{HB}$ to $85 \mathrm{HB}$ (Fig. 4a).

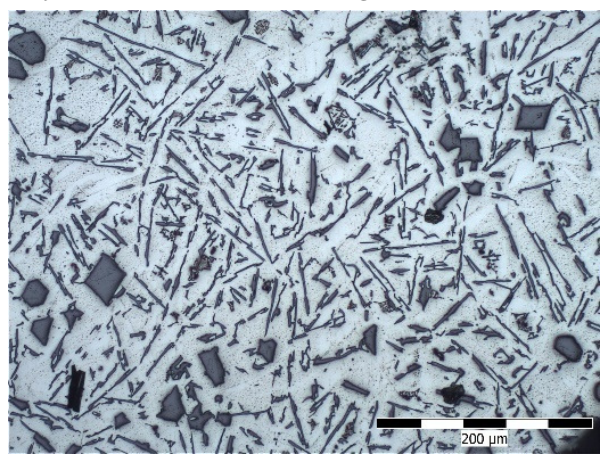

Fig. 1. Microstructure of raw AISi12 alloy, etched Mi8Al

a)

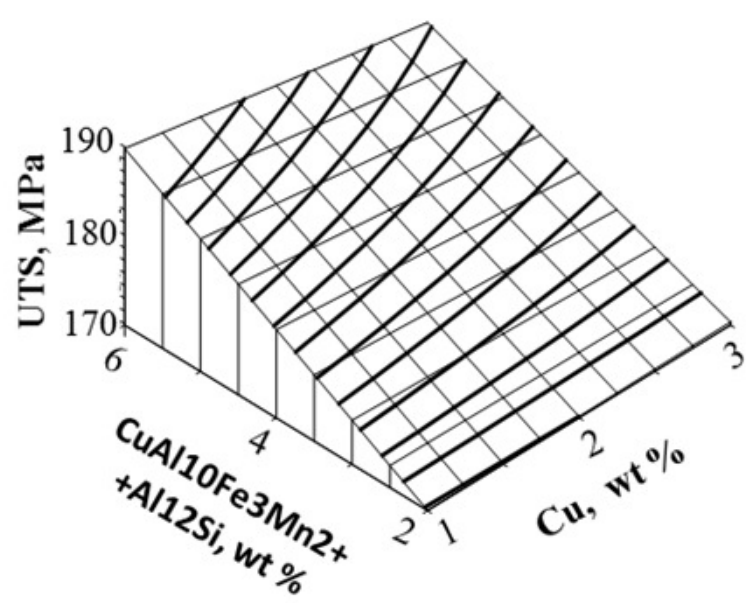

b)

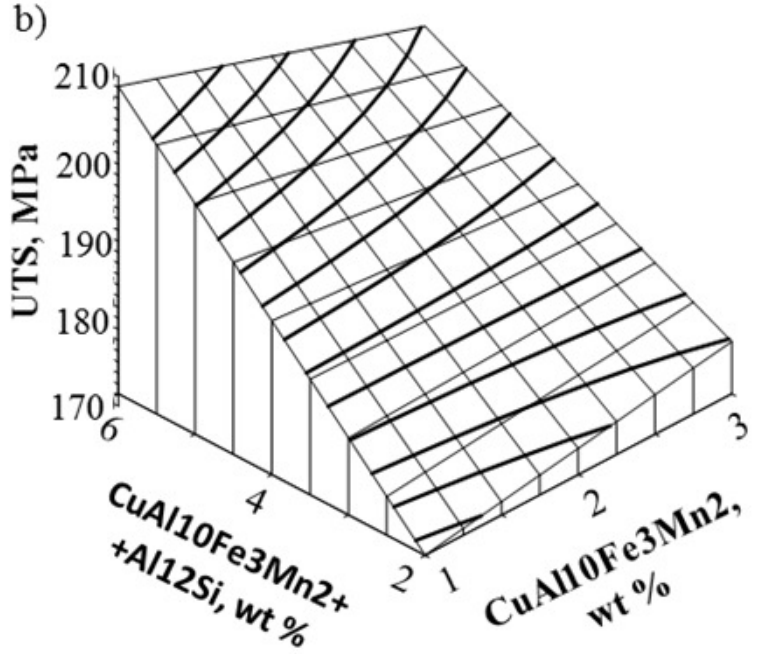

Fig. 2.Ultimate tensile strength (UTS) AlSi12 alloy: $\mathrm{a}-\mathrm{Cu} \in<1,3>(\%)$ and $\mathrm{Al} 12 \mathrm{Si}+\mathrm{CuAl} 10 \mathrm{Fe} 3 \mathrm{Mn} 2 \in<2,6>(\%)$ for $\mathrm{CuAl10Fe} 3 \mathrm{Mn} 2=1 \% ; \mathrm{b}-\mathrm{CuAl10Fe} 3 \mathrm{Mn} 2 \in<1,3>(\%)$ and $\mathrm{Al} 12 \mathrm{Si}+\mathrm{CuAl} 10 \mathrm{Fe} 3 \mathrm{Mn} 2 \in<2,6>(\%)$ for $\mathrm{Cu}=3 \%$

After increasing the content of $\mathrm{CuAl} 10 \mathrm{Fe} 3 \mathrm{Mn} 2$ of the mixture to $3 \%$ the ultimate tensile strength increased by $8 \mathrm{MPa}$ (by $25 \mathrm{MPa}$ comparison to raw alloy) to UTS $=178 \mathrm{MPa}$ (Fig. 2b), elongation by $0.4 \%$ to $\mathrm{A}=0.9 \%$ (Fig. 3b) and hardness to $\mathrm{H}=88 \mathrm{HB}$ (Fig. 4b). Treatment with $1 \% \mathrm{CuAl} 10 \mathrm{Fe} 3 \mathrm{Mn} 2++6 \% \mathrm{Al} 2 \mathrm{Si}+\mathrm{CuAl} 10 \mathrm{Fe} 3 \mathrm{Mn} 2+1 \% \mathrm{Cu}$ increased the tensile strength by $20 \mathrm{MPa}$ (by $37 \mathrm{MPa}$ comparison to raw alloy) to $190 \mathrm{MPa}$ (Fig. 2a), elongation by $1.0 \%$ to $1.5 \%$ (Fig. 3a) and hardness to $85 \mathrm{HB}$ (Fig. 4a). For all modifiers on higher level (Tab. 1) the tensile strength is $210 \mathrm{MPa}$ (Fig. 2b), elongation $2.5 \%$ (Fig. 3b) and hardness $92 \mathrm{HB}$ (Fig. 4b).

The microstructure of AlSi12 alloy with $3 \% \mathrm{CuAl10Fe} 3 \mathrm{Mn} 2+2 \% \mathrm{Al} 2 \mathrm{Si}+\mathrm{CuAl} 10 \mathrm{Fe} 3 \mathrm{Mn} 2$ $+1 \% \mathrm{Cu}$ is presented in Fig. 8a. The microstructure of AlSi12 alloy with $1 \% \mathrm{CuAl10Fe} 3 \mathrm{Mn} 2+$ $6 \% \mathrm{Al} 2 \mathrm{Si}++\mathrm{CuAl} 10 \mathrm{Fe} 3 \mathrm{Mn} 2+1 \% \mathrm{Cu}$ (the best mechanical properties) is presented in Fig. $8 \mathrm{~b} . \mathrm{A}$ little refinement of primary dendrites of the $\beta$ phase was observed after all processing of AlSi12 alloy in accordance to the investigation plane (Tab. 1). The analysed eutectic had a lamellar structure with a high degree of furcation. Analysing the microstructure of both alloys in both variants the likely occurrence of the grey needle-granular eutectic $\beta$ phase and grains white $\alpha$ phase were noted. And on a dark background in its turn eutectoid $\alpha+\gamma 2$ and dark precipitates of Chinese writings were noted. In Fig. 8b individually occurring separation of $\kappa$ phase can be observed. 
a)

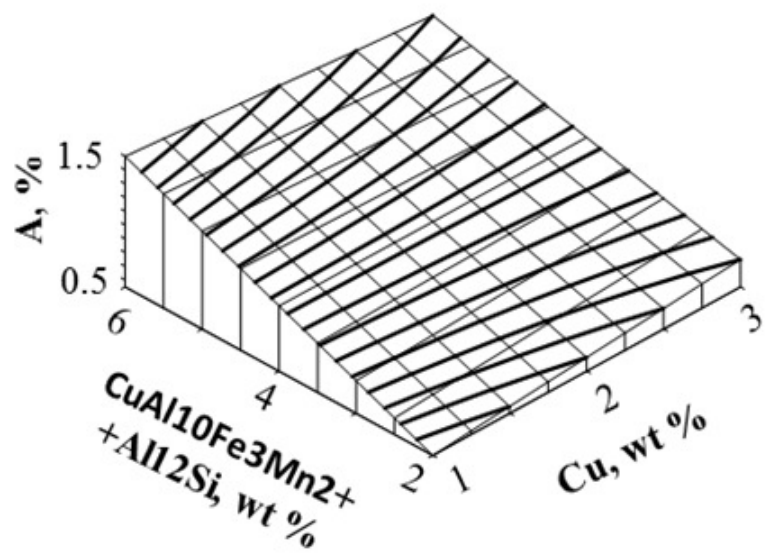

b)

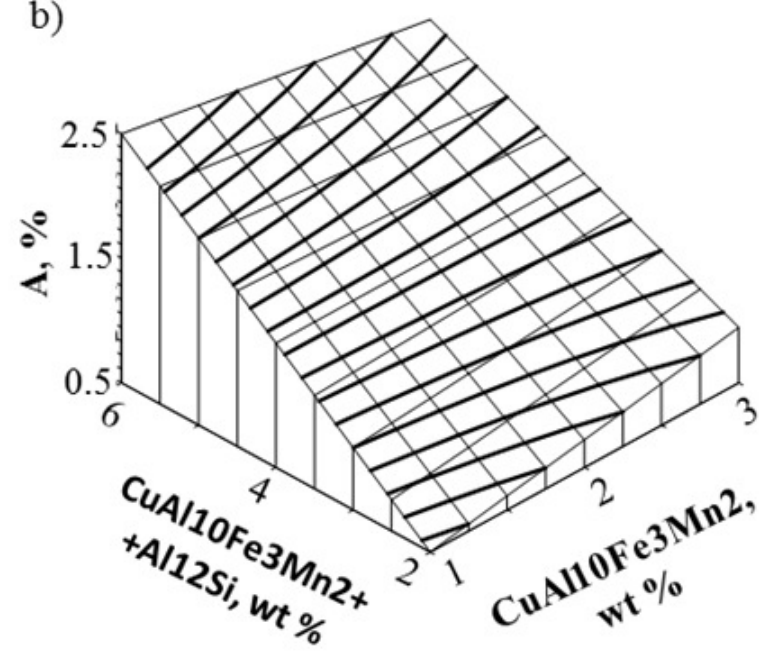

Fig. 3. Percentage elongation (A) AlSi12 alloy: $\mathrm{a}-\mathrm{Cu} \in<1,3>(\%)$ and $\mathrm{Al} 12 \mathrm{Si}+\mathrm{CuAl} 10 \mathrm{Fe} 3 \mathrm{Mn} 2$ $\in<2,6>(\%)$ for $\mathrm{CuAl} 10 \mathrm{Fe} 3 \mathrm{Mn} 2=1 \%$; $\mathrm{b}-\mathrm{CuAl} 10 \mathrm{Fe} 3 \mathrm{Mn} 2 \in<1,3>(\%)$ and $\mathrm{Al} 12 \mathrm{Si}+\mathrm{CuAl} 10 \mathrm{Fe} 3 \mathrm{Mn} 2 \in<2,6>(\%)$ for $\mathrm{Cu}=3 \%$

a)

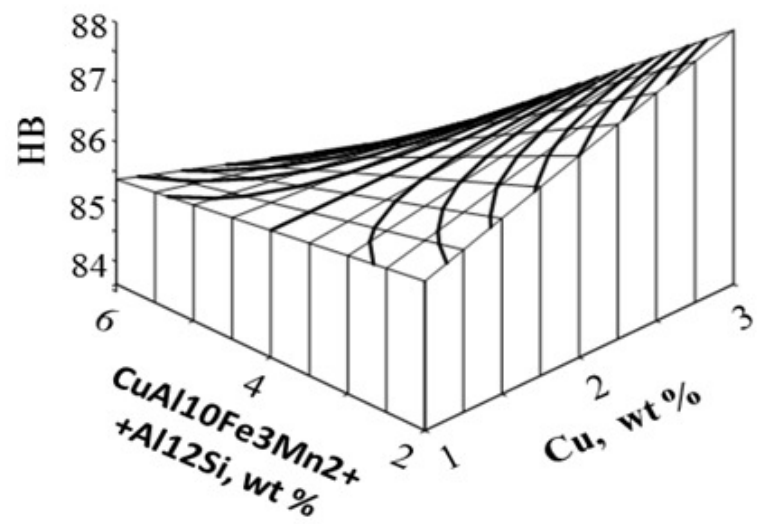

b)

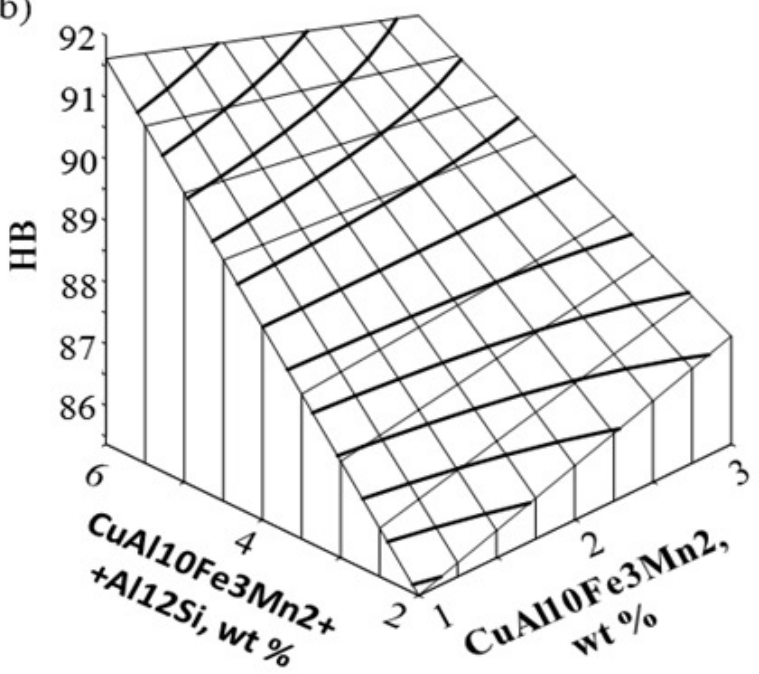

Fig. 4.Brinell hardness (HB) AlSi12 alloy: $\mathrm{a}-\mathrm{Cu} \in<1,3>(\%)$ and $\mathrm{Al12Si}+\mathrm{CuAl10Fe} 3 \mathrm{Mn} 2 \in<2$, $6>(\%)$ for $\mathrm{CuAl10Fe} 3 \mathrm{Mn} 2=1 \% ; \mathrm{b}-\mathrm{CuAl10Fe} 3 \mathrm{Mn} 2 \in<1,3>(\%)$ and $\mathrm{Al} 2 \mathrm{Si}+\mathrm{CuAl10Fe} 3 \mathrm{Mn} 2$ $\in<2,6>(\%)$ for $\mathrm{Cu}=3 \%$

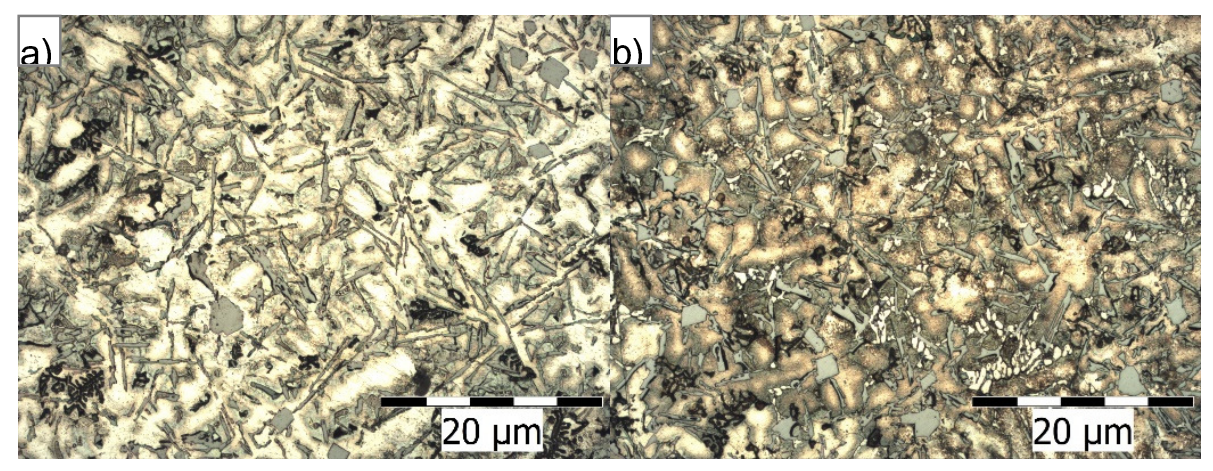

Fig. 8.Microstructure of AlSi12 alloy:

$\mathrm{a}-3 \% \mathrm{CuAl} 10 \mathrm{Fe} 3 \mathrm{Mn} 2+2 \% \mathrm{Al} 2 \mathrm{Si}+\mathrm{CuAl} 10 \mathrm{Fe} 3 \mathrm{Mn} 2+1 \% \mathrm{Cu} ; \mathrm{b}-1 \%$

$\mathrm{CuAl} 10 \mathrm{Fe} 3 \mathrm{Mn} 2+6 \% \mathrm{Al} 2 \mathrm{Si}+\mathrm{CuAl10Fe} 3 \mathrm{Mn} 2+1 \% \mathrm{Cu}$, etched $\mathrm{Mi} 8 \mathrm{Al}$ 


\section{Conclusions}

1. The results of the research showed the possibility of introducing CuAl10Fe3Mn2 addition to AlSI12.

2. The values of the tested parameters ( $\mathrm{Rm}, \mathrm{A}$ and $\mathrm{HB}$ ) of AlSi12 alloy depend on every component of the mixture.

3. The effect on the increase in mechanical properties can be shown descending: Al12Si + $\mathrm{CuAl10Fe} 3 \mathrm{Mn} 2$ followed by $\mathrm{CuAl10Fe} 3 \mathrm{Mn} 2$ and $\mathrm{Cu}$.

4. The best results were recorded for modifying with $3 \% \mathrm{CA}$ Al10Fe $3 \mathrm{Mn} 2+6 \% \mathrm{Al} 12 \mathrm{Si}+$ $+\mathrm{CuAl} 10 \mathrm{Fe} 3 \mathrm{Mn} 2+3 \% \mathrm{Cu}$, which enabled to achieve the highest values of all analyzed parameters (in this experimental design).

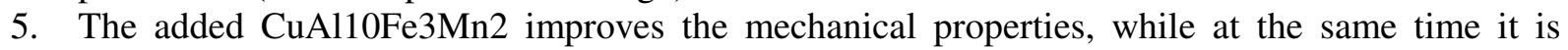
expected to reduce wear of the alloy due to friction and to reduce the tendency to blurring, which can translate into the economic performance and new areas of use.

6. The obtained results encourage to extend the research to determine the influence of the addition $\mathrm{CuAl} 10 \mathrm{Fe} 3 \mathrm{Mn} 2$ with base alloy on the microstructure and performance characteristics of hypoeutectic silumin, and in particular its tribological properties.

\section{References}

1. Michna S., Lukac I., Ocenasek V., Koreny R., Drapala J., Schneider H., Miskufova A. Encyclopaedia of aluminium, Adin s.r.o. Presov 2005. (in Czech).

2. Bolibruchová D., Richtárech L. Possibilities of Using Al-Si-Mg Alloys with Higher Fe Content for Demanding Castings. Manufacturing Technology 16(2) 2016, pp. 317-323.

3. Bruna M., Sládek A. Hot Tearing Evaluation of Al Based Alloys. Manufacturing Technology 16(2) 2016, pp. 323-327.

4. Pilarczyk W. The investigation of the structure of bulk metallic glasses before and after laser welding. Cryst. Res. Technol. 9-10, 2015, pp. 700-704.

5. Ulewicz R. Quality control system in production of the castings from spheroid cast ironvol. 42, 2003, pp. 61-63.

6. Wołczyński W, Guzik E, Wajda W, Jędrzejczyk D, Kania B, Kostrzewa M. CET in Solidifying Roll - Thermal Gradient Field Analysis, Archives of Metallurgy and Materials 57(1), 2012, pp. 105-117.

7. Wołczyńsk W., Sypien A., Tarasek A., Bydałek A.W. Copper Droplets Agglomeration / Coagulation In The Conditions Similar To Industrial Ones. Archives Of Metallurgy And Materials 62(1), 2017, 299-306.

8. Náprstková N., Kuśmierczak S., Cais J. Modification of AlSi7Mg0.3 alloy by strontium. Manufacturing Technology 13(3), 2013, pp. 373-380.

9. Lipiński T. Double Modification of AlSi9Mg Alloy with Boron, Titanium and Strontium. Arch Metall Mater. Vol. 60, Issue 3b, 2015, pp. 329-333.

10. Lipiński T. Modification of The Al-Si Alloys with the Use of a Homogenous Modifiers. Arch Metall Mater. Vol. 53/1, 2008, pp. 193-197.

11. Lipiński T. Modification of Al-Si alloys with the use of a homogenous modifiers. Archives of Metallurgy and Materials 53(1), 2008, pp. 193-197.

12. Náprstková N., Cais J., Stančeková D. Influence of Alsi7Mg0.3 Alloy Modification by Sb on the Tool Wear. Manufacturing Technology 14(1), 2014, pp.75-79

13. Lipinski T, Szabracki P. Modification of the Hypo-Eutectic Al-Si Alloys with an Exothermic Modifier. Arch Metall Mater. Vol. 58/2, 2013, pp. 453-458.

14. Lipiński T., Modification of Al-11\% Si Alloy with $\mathrm{Cl}$ - Based Modifier. Manufacturing Technology 15(4), 2015, pp. 581-587.

15. Bolibruchová D., Richtárech L. Effect of adding iron to the AlSi7Mg0.3 (EN AC 42 100,A356) alloy. Manufacturing Technology 13(3), 2013, pp. 276.281.

16. Nová I., Machuta J. Squeeze casting results of aluminum alloys. Manufacturing Technology 13(1), 2013, pp.73-79.

17. EN 1676:2010(E).Aluminum and aluminum alloys. Alloyed ingots for remelting. Specifications.

18. EN ISO6506-1:2014. Metallic materials -- Brinell hardness test -- Part 1: Test method.

19. EN ISO 6892-1:2016. Metallic materials. Tensile testing Part 1: Method of test at room temperature. 